\title{
Biomass Conversion To Fuels: A Challenge For Sustainable Growth In Mexico
}

\author{
Flory Anette Dieck Assad, ITESM-Campus Monterrey, Mexico
}

\begin{abstract}
During an adventure into a swine farmhouse in the municipality of Montemorelos, in the State of Nuevo Leon in Mexico, it was a real discovery to find out that well processed animal excrement is a potential source of wealth for the farm owner. This academic case presents the dilemmas for the construction of biodigesters that could help decrease environmental pollution through the trade of Carbon Bonds. Energy security, technological, and environmental concerns are the cornerstones of Sustainable Growth in Mexico, applied to this specific case. ${ }^{1}$
\end{abstract}

Keywords: Swine Farmhouse, Water pollution, Biogas, Carbon Bonds, Biodigester

\section{INTRODUCTION}

he road trip is over. Dr. Jaime Gonzalez got out of the car and proudly commented: - We finally arrived to Montemorelos, the citrus city of the state of Nuevo Leon, Mexico, get ready to taste the most delicious orange juice in the region!

It was a fieldtrip of a group of professors and friends who wanted to explore a city characterized for preserving its traditions and for being the nest of hardworking men, besides being the top producer of the best orange juice in the north of Mexico. We sat down at the well known restaurant "La Ponderosa" and enjoyed a beautiful landscape. While all of us praised the tasty orange juice, a friend of Dr. Gonzalez unexpectedly arrived to our table.

- What a great pleasure to meet you again, he said to Dr. Jaime Gonzalez, who immediately stood up from his chair and greeted his good old friend Mr. Jose Luis Tamez Tamez.

- I would like to introduce you, he said to the whole group, to a great swine cattle production leader in Montemorelos. This man, besides being an example to follow, is the President of the Swine Farms Union of Nuevo Leon, which is integrated by 120 swine cattle producers.

We all stood up from our chairs to welcome and invite him to chat with us for a while. This casual encounter would make our exploratory trip an unforgettable experience. Mr. Jose Luis Tamez Tamez, with a remarkable humbleness, a great sense of humor and a positive attitude, with a hard worker charm, and a generosity that characterizes Montemorelos's citizens, sat with us and gladly agreed to share his knowledge about the challenges that swine cattle producers were facing worldwide.

\footnotetext{
${ }^{1}$ This Academic Case was written with the objective of serving as course discussion material where students can learn about the great challenge of Sustainable Growth with an emphasis in pollution control in the swine farms in Mexico. Its emphasis is centered in the use of financial strategies, through the trade of Carbon Bonds, in order to trigger the swine farms' growth with sustainable and ecological criteria. It can be used with the author's permission and the request of the Teaching Note for academic purposes. This Academic Case was written with the information given by Ana Margarita Swine Farm, located in "Camino a la Cascara Km. 2.5", Cascara, in the municipality of Montemorelos, in the State of Nuevo Leon, in Mexico, where this case was researched. Some data has been altered to maintain confidentiality of the information. I want to extend my deep gratitude to Mr. Jose Luis Tamez Tamez, President of the Swine Farms Union of Nuevo Leon, Mexico, and owner of the Ana Margarita Swine Farm. I want to thank him for his generosity, his time and great talent with which I could write the present Case.
} 
Our unforgettable adventure started when the owner of the Ana Margarita swine farm, that has an extension of 70 hectares (172.97 acres) located at the Montemorelos municipality, started to tell us about the ecological and sustainable projects of his farm. ${ }^{2}$ It was a positive impact to learn that this small city was inhabited by fully talented men with indisputable human quality, like Mr. Jose Luis Tamez Tamez, who during the course of our pleasant conversation managed to awaken an ethical consciousness in favor of the Earth within us. Nobody could have imagined that important topics such as ecological and sustainability dilemmas were so seriously discussed, in such a small city, with the same criteria as in the United Nations (UN).

\section{A CHALLENGE TO SWINE PRODUCTION}

Our group of professors was so enticed with Mr. Tamez's interesting conversation, that we invited him to stay the whole day, and kindly requested him to explain to us the strategic challenges of the swine farmhouses he represents as the leader of the Swine Farms Union of Nuevo Leon.

In a way of supporting our petition, Dr. Jaime Gonzalez commented: “- Each professor in this fieldtrip has diverse knowledge and disciplines, but we share the same mission: to discover and learn".

Mr. Tamez was touched by our great interest on the subject, and he gladly agreed to introduce us to the discovery of the problems that swine farms in Nuevo Leon were facing. And this is how his pleasant chat started:

- I think that it is an already well known fact that environmental pollution generated by animals as a consequence of intensive exploitation practices exists. Due to the production growth and the animal population increase, our biggest strategic challenge is to become a less polluting producer, said Mr. Tamez with great seriousness. The great capacity of pigs to adapt to very different climates, have made them easy to be exploited in every continent and almost in every country, with exception of those countries where, for religious and cultural reasons, their existence is forbidden (FAO, 2001).

The Food and Agriculture Organization of the United Nations (FAO), estimated that the world swine population at the beginning of this millennium was 907 millions of pigs distributed in the following way (FAO, 2001):

\begin{tabular}{llc} 
Continent & Country & Millions Of Heads \\
\hline Asia & China & 534 \\
& Vietnam & 437 \\
Europe & 19 \\
Latin America and Caribbean & 204 \\
& & 73 \\
U.S.A. and Canada (North America) & MEXICO & 15 \\
Africa & 72 \\
Oceania & 19 \\
THE WORLD & 5
\end{tabular}

- Then Susana, one of the professors of the group, asked: So then, is China the highest polluting country on matters of swine exploitation?

- That's exactly right, replied Mr. Tamez. And Mexico contributes with a population of 15 million heads of swine cattle; well, to be exact, a total of 15.257 million heads in 2006, according to the last available official statistics. ${ }^{3}$ This number is still below the 19 million heads reported by Vietnam.

\footnotetext{
${ }^{2}$ During the conversation, Mr. Jose Luis Tamez cleared up that all of the economic activity of his farmhouse, even though geographically located in the city of Montemorelos, was performed in the city of Allende, in the same state of Nuevo Leon. Therefore, when people talk about his farmhouse, many think of it as being located in the city of Allende, Nuevo Leon.

${ }^{3}$ INEGI, 2008.
} 
- Furthermore, continued Mr. Tamez explaining with great patience, the hog's fecal excretions of this swine exploitation (also known as "hog excreta") include fecal and urinary excretions, food waste and water resulting from washing the cattle plus the involuntary losses of water itself, together with other materials such as hay and sawdust used as "bedding" at the swine farmhouses. Therefore, the potential pollutants resulting from the animal exploitation have all an organic origin. This waste could have variable water content, even sometimes being totally liquid. Nevertheless, the solid fraction can be distinguished either as the total suspended solids (TSS), which is the recoverable portion obtained by filtration, or as the total dissolved solids (TDS). The sum of both fractions is called "total solids" (TS), which are precisely the ones that produce methane gas, a very polluting substance.

Mr. Tamez stopped talking, took out a FAO (1997) book from his briefcase, and told us: - In order to be precise, I would like to read this text to you out loud: "The organic character of the hog excreta allows it to get incorporated to the natural chains of nitrogen and carbon cycles, and that is the reason why, if properly used, they constitute a potential source of wealth. Generally, they are used as a fertilizer with the purpose of soil improvement. But also, they are used in integrated production systems to feed fish and ducks". - One could say, Mr. Tamez continued talking with enthusiasm, hog excreta is also becoming relevant when fattening up ruminants, either as a secondary activity of pig-breeding in the management of fecal excretions at the same farm, or as a product to be exported for intensive breeding of other cattle farms. The activity of recycling hog excreta, or recovered solids, is a good option to control the aforementioned pollution.

- I would have never imagined, Susana said. How it is possible to think that hog excreta produced by pigs could be a potential source of wealth. This is truly impressive!

- That's right, Mr. Tamez said. In general, the handling of hog excreta does not represent a real problem in Mexico, since, as I will tell you later on, there is abundant soil in need of fertilizers and the possibility of recycling the hog excreta on animal feeding, as well. Thus, we have the opportunity for pollution control.

The underlying success in the management of hog excreta consists on maintaining equilibrium with the environment they are spilled into (soil, water or animal production), which demands knowledge about the composition of the excreta and the receptor itself. Despite what has been said about the management of solidsstated Mr. Tamez with a worried expression on his face-, water (or the liquid portion of the excreta), requires particular consideration, fundamentally because its potential pollution is derived from the presence of organic material in it, which is measured in function of the solid content. Indeed, water is our biggest concern!

When Mr. Tamez saw our confused face expressions, he wisely stated: -I would like to use pig's offal as an example. This is the name we give to the hog excreta used to feed fish. The pig's offal requires oxygen just as fish do (O2 dissolved in the water), therefore, pig's offal should be treated first before it could be used as fish food. Usually it is oxygenated with pumps. The particular characteristic of lagoons where fish are grown is that the available $\mathrm{O} 2$ is scarce, so it should be supplied artificially. Water from a lagoon that produces fish does not have the same amount of properties as the water from a river.

- Dissolved oxygen in the water, is an important parameter for water quality, Mr. Tamez pointed out with a convincing voice. In waters where organic material content is high, the dissolved oxygen should be measured through membrane electrodes. Waste water creates a demand for oxygen, which has to be supplied by dissolved oxygen in the receptor bodies (the lagoon where this water is poured), if not, the biological balance will be disrupted.

- I will explain it in a simpler way, said Mr. Tamez, if the organic load poured into the water is below the assimilation capacity of the receptor water, then the required aerobic conditions will remain for the normal flora and fauna; if the quantity is exceeded, then an excessive bacteria proliferation will consume all the oxygen, creating conditions for anaerobiosis. Let's remember that high quality waters should be able to support life.

- According to research papers published by FAO (1997, p. 123), continued explaining Mr. Tamez, fecal excretions and water should be considered as two independent resources, that, when mixed together, affect each other negatively: the solids reduce water quality and consequently water has to receive the required treatment in order to 
be reintegrated into the environment; on the other hand, fecal excretions lose their nutritious value, due to the aqueous dilution, or by other solids dragged along.

- Let's get to a conclusion, Mr. Tamez said emphatically. Undoubtedly, hog excreta can be a potential source of wealth if considered not as a waste, but as a raw material readily available all year long for recycling. Our biggest challenge towards the environment is to control water pollution, therefore the first step in order to control fecal and urinary excretions is to recover the solids, which means, to remove most of the organic matter from the water.

- Therefore, he emphasized, the need to process hog excreta could not be any clearer. But before implementing any system, some factors should be considered: the chosen system should permit an adequate cleaning process for the farm, it should facilitate the removal of feces, consume low quantities of water, need lower labor, preserve the fecal nutritious properties, make it easy to store proper amounts, suppress any offensive odor emissions, and it should eliminate all pathogens.

Farmyards are cleaned up by a sweep and drag system in $80 \%$ of swine exploitation cases around Mexico, which facilitates the recovery of solids in the hog excreta recycling process. - The crucial thing is, said Mr. Tamez in an inquisitive manner, to find a convenient, economical and practical strategy that would benefit both the environment as well as the producers.

\section{ANA MARGARITA SWINE FARMHOUSE}

The group of professors and I were impressed by the outstanding explanation of the challenges of swine cattle exploitation that Mr. Tamez was telling us about. We stopped the conversation when Dr. Jaime Gonzalez kindly asked for a new round of delicious orange juice for everybody, together with some Mexican appetizers.

We were suddenly impressed by our intrepid colleague Simon, because we all wanted to inquire even more on the debated subject matter, but before anyone said anything he popped the question we were all thinking about, and in a very polite and direct manner he asked: - Mr. Tamez, we have already understood all the general characteristics of swine exploitation, but at this point of the journey, we are now interested in getting to know your opinion about the best practical and economical strategy that would benefit your farmhouse Ana Margarita particularly as well as the swine production farms in the State of Nuevo Leon.

Staring at Simon, Mr. Tamez wisely replied: -the question that you just asked me is precisely the most important dilemma for any producer. This is exactly the dilemma that swine farms in Nuevo Leon are now facing and should solve. But let me give you a broader explanation of some other specific characteristics of swine exploitation in Nuevo Leon.

- First of all, let's talk about some of the environmental factors which swine cattle production has to fight against: temperature and humidity. The thermal capacity of pigs is limited as a consequence of their fattening tendency and their small lungs, and should be regulated in function of their age and physiological state. Pigs are in thermal equilibrium with the environment when the temperature is lower than their body's (Serres, 1997 y Rinaldo y Le Dividich 1991). Pigs' thermo-regulator is somehow defective because they lack sweat glands (pigs do not sweat), similar to reptiles, therefore they always want to be in the water or in mud - when available - in order to regulate their body temperature. The farmhouses in Nuevo Leon pollute a lot because they use large volumes of water to perform chores such as cleaning and, as just mentioned, maintaining the pigs' body temperature. As a consequence large quantities of solids, resulting from feces and food leftovers, are dragged away altogether with a considerable amount of methane gas (biogas) that could be also used for energy production.

Mr. Tamez took some photographs out of his briefcase, and continued teaching us- In order to reduce pollution at swine farmhouses, machines that separate solids are used to reduce, on a large scale, the degree of fecal matter pollution of the water; nevertheless, this is not enough.

- As we have been talking, Mr. Tamez started to recapitulate, the hog excreta can be used as a soil fertilizer for agricultural purposes, or for the growing of fish, birds, and ruminant nourishment, or as raw material in biodigesters. 
In our case, the hog offal is mainly used to nourish sheep and cattle. For fish nourishment, as I mentioned before, one should be more careful because the oxygen at the lagoon where fish are grown could be seriously affected.

-Let's look at the following statistics, Mr. Tamez assertively stated; a pig from our farms eats approximately $3 \%$ of its weight every day. So if a pig weighs $100 \mathrm{Kg}$, it gets fed with $3 \mathrm{Kg}$ of balanced food. Its monogastric quality forbids it from accumulating ingested food for long periods of time so digestion occurs rapidly. ${ }^{4}$ This situation forces producers to feed pigs on a daily basis. Even though their stomachs are not relatively big, their intestines can be as large as twenty times their body size, which results in an easy adaptation to the different nourishing regimes and to the assimilation of food rich in cellulose in cases where pigs are pastured, or rich in proteins in cases where pigs are nourished with meat leftovers. (Zhou et al., 1997).

- Going back to the generation of fecal excretions at the Ana Margarita farmhouse, explained Mr. Tamez, its owner, we estimate that the average weight of a pig in a full cycle farm is $54 \mathrm{Kg}$, and it is estimated that the food that our swine cattle digests has an average of $80 \%$ digestibility (what is absorbed).

-Thus, Mr. Tamez added with technical precision, in my farmhouse, Ana Margarita, where we have 10,000 pigs, and we estimate an average weight of $54 \mathrm{Kg}$ per pig, if we make some calculations, we would get the following result of feces generation per day:

\begin{tabular}{|c|c|c|}
\hline & 54 & Kg (Pig's average weight) \\
\hline $\mathrm{x}$ & .03 & ( $3 \%$ of its weight in ingested food) \\
\hline$=$ & 1.62 & $\mathrm{Kg}$ of food per pig per day \\
\hline - & $80 \%$ & of digestibility \\
\hline$=$ & 0.324 & $\mathrm{Kg}$ (feces per pig per day in matters of dry feces) \\
\hline$\underline{x}$ & 10,000 & pigs at Ana Margarita farmhouse \\
\hline$=$ & 3,240 & $\mathrm{Kg}$ (feces generated per day at this farmhouse) \\
\hline
\end{tabular}

- In particular, he concluded, my farmhouse Ana Margarita generates approximately 3.24 tons of feces per day, a source of potential wealth, isn't it? I have to mention that this number is only an average in order to get a rough idea about the amount of feces that are generated. In order to be more technical about the nourishment of the pigs, it is important that you know that food is accessible all the time (nourishment is available in containers and they can eat as much as they want) for the pigs 7 days after they are born until they are sold. This same procedure occurs with female milking pigs. In the case of pregnant pigs and studs, food is a bit more restrained and they are given between 2 and $3 \mathrm{Kg}$ per day per animal, depending on the physical state of each.

- In 2009, there were 62 registered swine farmhouses operating in Nuevo Leon, commented Mr. Tamez, with a population of approximately 250,000 pigs. Can you imagine the amount of feces that is generated per day just in this state? Approximately 81 tons of feces per day!, expressed Mr. Tamez completely astonished.

Mr. Tamez recapitulated: - Going back to Simon's initial question, the members of our Union are farms labeled as intensive or production intensive, even though some of the farms are small, this is, they have between 800 and 1500 pigs in total. ${ }^{5}$ Those that are labeled as intensive farms are characterized by having pigs with good genetics and they are crossbred in order to obtain hybrid vigor, balanced nourishment according to the animal's production level, proper facilities for each stage, and an adequate temperature control for areas that require so. In this type of exploitation farms, our production is totally programmed, from getting the female pig pregnant until the pigs are sold. We have a vaccination calendar and external/internal parasite controls, with the main objective of doing business. The animals are always confined in small areas, there are a large number of animals which have a

\footnotetext{
${ }^{4}$ A monogastric animal (pigs, birds, fish, and rabbits, among others) has a simple stomach with a small storing capacity. Some ruminants have more than one stomach. For example, the giraffe is a ruminant that has 4 stomachs.

${ }^{5}$ Some other farms that are not production intensive exist, such as small family owned farms that do not represent business alone. These farmhouses are more like a hobby or as a way of saving up money for families. Generally, they have proper facilities and they feed the swine cattle very well. There are other farmhouses known as "backyards" where the animals regularly live on a free range style or they are encompassed at rustic corrals and get bad nourishment made up of leftovers.
} 
minimum space for each of their stages. In these exploitations we are looking for transformation of environment residuals of high biological value to feed the cattle. The most interesting thing about our strategy is the treatment of residuals at swine farmhouses for energy production (Biogas).

- We chose the construction of biodigesters, Mr. Tamez commented, because it would also help our farms to satisfy the Mexican norm on water pollutants. In the past, he said, there was no norm that established a criterion for the treatment of residual water in order to be reutilized for the public, for direct, indirect or occasional contact. In 1998 the norm NOM-003-ECOL-1997 was published, establishing the maximum permissible pollutants for treated residual waters. This norm had the objective of protecting the environment and the population's health. The official norm, not only regulates residual water outflows, but it also proposes benefits that could be obtained by designing an action plan for water cleaning. Among these benefits there are fiscal incentives consisting on reducing by $100 \%$ the investments on equipment to prevent and control the environmental pollution (Budedo, 1997), and the possible exemption of the corresponding tax payment for polluted residual waters according to the Federal Rights Law (Ley Federal de Derechos). ${ }^{6}$ The time span to fulfill the norm was 10 years, year 2007 being the deadline. But because most of the farms did not fulfill it, there was an extension until 2012.

Mr. Tamez showed us statistics stating that the applicable norm to swine cattle discharges into the water had a maximum permissible limit of 1000 coliform units (colony forming units) per 100ml. ${ }^{7}$ In 2009 we have already lowered it to 24,000 coliform units per $100 \mathrm{ml}$. Working according to this norm is already crucial for operating our farms. We need an urgent improvement on this aspect! The maximum permissible limit for fecal coliform units is impossible to reach with a simple secondary treatment. ${ }^{8}$ However an increased anxiety prevails (Belausteguigoitia, 1997) because at some point in the near future, the environmental arguments could also be used as barriers to international trade.

- We greatly value pig feces, Mr. Tamez concluded, considering that its recycling process would be very successful if it resulted in the production of biogas, and estimating that feces of an adult pig can produce from 0.28 to 0.34 biogas cubic meters. This would be our best strategy that could be achieved through the construction of biodigesters. This is precisely the strategy that is currently under study in our Swine Farms Union of Nuevo Leon.

\section{BIOGAS PRODUCTION AND ELECTRIC ENERGY GENERATION AT SWINE FARMHOUSES IN NUEVO LEON: THE BIODIGESTERS}

We, the group of professors and friends, had all understood the problem so far, but our minds were rapidly searching for a solution to the dilemma of the Swine Farms Union of Nuevo Leon. This became our challenge!

After we all enjoyed a break savoring a delicious coffee, Simon firmly questioned Mr. Tamez one more time, wanting to investigate about the obstacles that blocked a practical solution for biogas production for Nuevo Leon's swine farmhouses.

- The greatest obstacle of all, replied Mr. Tamez, is the resistance to confront the environmental issue because it is considered that its solution only represents a cost and not a benefit. Besides, there is a lack of knowledge about the real costs of the diverse treatments and recycling systems. Due to the energy price increase, and as a way of reaching "sustainability" of swine production, at the Swine Farms Union of Nuevo Leon, we decided to spread the voice about the ecological and economical importance of hog excreta recycling in order to convert it in clean water, in organic fertilizers, in ruminant nourishment consumables, and as a source of biogas. This was the beginning of an

\footnotetext{
${ }^{6}$ In order to better understand the swine farmhouse dilemmas, it's vital to be well acquainted with the environmental and fiscal legislation and the valid norms. The most important are: The General Law for Ecological Balance and Environmental Protection (Ley General del Equilibrio Ecológico y la Protección al Ambiente), National Water Law (Ley de Aguas Nacionales), General Health Law (Ley General de Salud) and Federal Rights Law (Ley Federal de Derechos).

${ }^{7}$ Coliform unit is the collective term that refers to diverse types of negative intestinal bacillus such as: Escherichia, Enterobacter or Klebsiella. They are used as an indicator for biological pollution of the water, especially for drinking water.

${ }^{8}$ According to the norm that is applied to discharging feces into the water in the swine farmhouse case, fat, oil, $\mathrm{PH}$, and coliform contents are considered. For tax payment purposes the only parameter taken into consideration is the existence of coliform units.
} 
important project for our farms; our target was the biogas production and electric energy generation through biodigesters.

- Building biodigesters is the core task of the aforementioned project, through which the biogas production could be stored and controlled, and the residual water could be cleaner, Mr. Tamez explained with great kindness and patience. In our farms, methane, which is 21 times more polluting than carbon dioxide and is produced by the solids contained in the water, is burned. Thus, biogas also known as "young methane" is caught through a burning process, which hinders the gas to go into the atmosphere causing pollution.

Professor Sandra interrupted Mr. Tamez asking him for a broader explanation of what a biodigester was because even though she knew a lot about international trade, still she didn't have deep knowledge about this concept.

- A biodigester, Mr. Tamez replied with a smile on his face, is basically a pit of variable dimensions according to the farm size and the amount of waste it generates. This pit is lined with a canvas or a liner, covering both the pit and the upper part of it, forming a balloon-like bubble that is where the generated gas is stored.

- Let me clear this up for you guys, said Mr. Tamez raising his voice, big advantages exist with the use of biodigesters, I would like to emphasize the following: low cost, easy to build, easy installation and handling, minimum maintenance (no sophisticated maintenance required), increase in profitability of swine production exploitation, maintenance of the fecal fertilizer value (half of the organic nitrogen is turned into ammonia), sedimentation as mud with small phosphate and potassium quantities (to use as fertilizers), and the reduction of the odor problem generated by the storage of feces at the farmhouse. ${ }^{9}$

- The process consists in sending or transporting the water containing all the farmhouse solids into the biodigester, crossing the whole length of the farm, Mr. Tamez continued excitedly and pleased with our real interest in his dilemma. This allows the solids to remain at the digester, and through the digestion process methane gas is generated. It is estimated that only $10 \%$ of all the incoming solids remain as mud or compost. Therefore, from each ton of solids that comes into the biodigester, only $100 \mathrm{Kg}$ of mud will remain. Mud is extracted approximately every 8 months through some pipes that go all the way down deep into the digester, injecting hot water to remove and suck them up with a pipe or with some extraction mud bombs. In this process, the water that comes out of the digester practically does not contain solids anymore, and can be properly used for agricultural irrigation, mainly for pasture fields. At the same time, the official norm established by the National Water Commission (CONAGUA in Spanish) in relation with the maximum solid contains limits in residual waters is fulfilled.

Professor Sandra interrupted again, - Excuse me, Mr. Tamez, but the concept of a biodigester is still not quite clear for me. Would you be so kind to explain to us in a more precise detail how it works?

- Of course! Mr. Tamez replied, very pleased to have awakened so much interest on the subject. The biodigester carries out an anaerobic process immersed in water. The process called decomposition or digestion of the solids, starts when feces enter into the biodigester, similar to what happens in the stomach of an animal. It is estimated that $90 \%$ of the solids are transformed into biogas during the process (with the composition of $62 \%$ Methane (CH4), $30 \% \mathrm{CO} 2,7 \%$ water vapor and $1 \%$ of other gases including hydro sulfuric acid with approximately 200ppm); the other $10 \%$ is what we call mud sediment or compost which regularly is left at the bottom of the digester. ${ }^{10}$ This is the way to get a compost of the best quality which could be used for agricultural field fertilization, and in a near future, it could be also traded at an attractive price to be used in gardens because it has no odor and it represents no pollution risk. After extracting the compost or mud sediments, they could be sent directly to the fields, because the

\footnotetext{
${ }^{9}$ Ammonia is the basis for nitrogenous fertilizer production. All of the fertilizer production projects require the production of composed substances that will provide the necessary nutrients for plants: nitrogen, phosphorous and potassium, either individually ("simple" fertilizers), or as a combination ("mixed" fertilizers).

10 The measurement "ppm" means "parts per million concentrations".
} 
nutrients in them are ready to be assimilated by crops, together with the water. ${ }^{11}$ Another way of using the compost or mud sediments would be by their deposit in a dam or a dry lagoon, and wait until they get dehydrated in order to be used as fertilizers afterwards. In our case, this is an easier way to do it because this type of mud has no dangerous residuals such as heavy metals, industrial or hospital waste, since this compost or mud sediments are the product of only what the pigs eat, and their nourishment is totally balanced. There could also be a secondary lagoon at the outflow of the biodigester, in order to collect the water and send it for agricultural irrigation later.

-The most crucial moment is here! Mr. Tamez exclaimed. During the digestion process methane gas is produced, which is collected through a perforated pipe that goes inside and around the digester. Methane gas is conducted through some PVC pipelines and other type of ducts to a meter that corroborates its production volume which generates the Reduced Emissions Certificates (RECs) or Carbon Bonds resulting from the burned methane gas. Then it goes through a blowing fan to be conducted to the burner in order to avoid pollution into the atmosphere.

\section{KYOTO PROTOCOL AND THE CARBON BONDS}

When Mr. Tamez mentioned the generation of the REC's or Carbon Bonds, he was immediately interrupted by Karina, the professor with great expertise in finance, and with a questioning look said: - Would you please explain to us, Mr. Tamez, the relationship between the burning of methane gas by the biodigester made out of swine feces with the generation of Carbon Bonds?

- Sure Karina, Mr. Tamez replied, on December $11^{\text {th }}$ of 1997 , the industrialized countries got together at Kyoto, Japan and they were committed to execute a set of measures in order to reduce greenhouse gas emissions. These are: water vapor, carbon dioxide, methane gas, nitrogen oxide, ozone, and artificial refrigerants. Governments that signed the Kyoto Protocol agreed to reduce an average of 5\% of polluting emissions between 2008 and 2012 taking as reference 1990 levels. For example, if during 1990 the pollution of these gases reached $100 \%$, at the end of the year 2012 the percentage should be $95 \%$. The agreement began to take effect the $16^{\text {th }}$ of February of 2005 . The objective of this international agreement is to limit the greenhouse gas emissions globally. Mexico, itself, signed the agreement of the United Nations Framework Convention on Climate Change (UNFCCC) the $7^{\text {th }}$ of May, 1993, and ratified the Kyoto Protocol the $24^{\text {th }}$ of November, 2000. Additionally, the $25^{\text {th }}$ of April, 2005, the Mexican Official Federation Journal (Diario Oficial de la Federacion) announced the creation of the Mexican Climate Change Commission (Comision Intersecretarial de Cambio Climatico), constituted as the Mexican National Authority designated to write the approval letters for the projects related to the reduction of polluting emissions and the capturing of greenhouse gas emissions.

- I'm telling you all of this, Mr. Tamez said to Karina, so you know that the necessary legislative framework already exists in Mexico, so we could now venture into the so promising international Carbon Bonds market. The Kyoto Protocol establishes mechanisms where emerging markets can help industrialized countries fulfill their commitments on greenhouse gas emissions reduction. These mechanisms are: Emissions Trade and Clean Development Mechanism (CDM), which indeed represents an interesting opportunity for Mexico's participation. If we succeed in generating a CDM project that reduces greenhouse gas emissions as the biodigester does, then the methane gas emissions that we achieve to reduce can be certified, and after Reduced Emissions Certificates (RECs) are generated we can sell them to industrialized countries so they can fulfill their emission reduction goals. This way, the RECs or Carbon Bonds that we succeed to certify, can be sold in the international Carbon market either to enterprises or governments of several countries. The income that we, farmers, could get through the sale of RECs, could be used to finance the biodigester construction project, of course, once the construction had been approved as a CDM project by the United Nations (UN). It was decided to have a specific measurement unit as a trade exchange base in this emissions market, the $\mathrm{CO} 2$ ton was chosen as such unit, known as the "Equivalent Carbon". A Reduced Emissions Certificate (CER) is equivalent to a carbon dioxide ton that is not emitted into the atmosphere at all and that can be sold at the Carbon market to industrialized countries.

\footnotetext{
${ }^{11}$ In order to send the compost or mud sediments as fertilizers to the fields in a state of mud that still has water content, it has to be done only when the economic possibility for their distribution exists. This is due to the special equipment needed to handle liquids or semisolids which impacts the cost of this process.
} 
In the projects listed by the UN as those that capture gas emissions, we can find the following: recovery of methane gas from mines, landfills, and/or farms, with the purpose of burning it, or to generate electricity taking into advantage the energy produced by the burning process. In this specific area is where we, swine production farmers of Nuevo Leon, could actively participate. In practical terms, it is estimated that a Carbon Bond could be obtained for each pig per year. In my particular case, we could have 11,200 CERs as a registered base line, of course, if we have the required animal inventory.

- According to the Kyoto Protocol guidelines, Mr. Tamez insisted, the methane gas generated by the biodigester, would be property of the producer and could be used by him with the condition that all of it should be burned, that no methane residuals are left, and that everything must be transformed into carbon dioxide, having the biodigester's wick permanently burning.

Methane gas can also be used as a heat source in heating systems for small pigs or as a fuel replacement to keep motors running at the farmhouse or at the employees' houses, or for electrical energy generation to use at the farmhouse, and/or to be sold to the Mexican Federal Electricity Commission (Comisión Federal de Electricidad or $\mathrm{CFE}) .{ }^{12}$

- If we succeed to get support from the United Nations (UN) to build the biodigesters, Mr. Tamez commented in a nostalgic manner, there would be no cost for the producers; on the contrary, they would get all the benefits from the generation and sale of Carbon Bonds, or the Reduced Emissions Certificates (RECs) (Merla 2009). The enterprise that would build the biodigester, endorsed by the UN, would recover its investment with the Carbon Bonds sale at the stock exchange market, leaving an approximate profit of $10 \%$ of their value to the swine farms. All this process would be performed by Specialized Financial Institutions, with a process that I will explain to you all a little bit later. Every swine production farmhouse, depending on its dimensions, could produce around 5,000 Carbon Bonds from which the farmhouse could get an income calculated around \$150,000 USD, in a scenario where the bond would be quoted at $\$ 30$ USD. ${ }^{13}$ Part of this income, as I already mentioned, would go to the swine farms.

- Going back to technicality, Mr. Tamez added, Carbon Bonds are an international mechanism aimed to reduce polluting emissions into the environment. The U.S.A is now discussing the implementation of an internal carbon market similar to the European one that could boost demand for RECs from 2012 onward.

Karina interrupted again and with an inquiring look, she approached Mr. Tamez with a unique passion for learning and posed a new question: - How many pigs should be included in order for the UN to accept an investment project for Carbon Bonds generation?

- Excellent question, Mr. Tamez replied enthusiastically. The UN does not ask for a specific number of pigs, the problem is that the registration cost of the program at the UN is the same for either 1,000 or 100,000 animals. Due to its high registration cost, in order for it to be profitable, farmhouses need to have a large number of animals. Another high cost that has to be considered is the one related to the yearly auditing process.

- It is important to point out, Mr. Tamez emphasized, that in order to generate Reduced Emissions Certificates (RECs), a greenhouse gas emissions reduction project must fulfill the procedure established by the Kyoto Protocol and by the Marrakech Agreements, which could be summarized in two: make a study for the feasibility and design of the project and present the documentation required for the Clean Development Mechanism (CDM). In order to fulfill the requirements, there are Specialized Financial Institutions such as MGM International Group (MGM Carbon Portfolio), JP Morgan, Ecosecurities and AGCERT, among others, which could offer support to the swine farms. The cost of the process in time and money is too high for only a single farmhouse; therefore, we have been thinking that several farmhouses could get together. The objective would be to have a project that could support 9 farms so that each one could build a biodigester and have a motor for electric energy generation.

\footnotetext{
${ }^{12}$ The CFE (Mexican Federal Electric Commission) is the only state-owned company that produces electric energy in Mexico.

${ }^{13}$ Carbon Bonds are quoted in the Stock Market and their price is based on their free market according the law of supply and demand.
} 
- Now, Mr. Tamez concluded, if the biodigester would contribute to avoid methane gas emissions into the atmosphere, to reduce water pollution, and to generate electric energy to be used at the swine production farmhouses, could you, talented group of professors, help us understand the process of Carbon Bonds generation? How could we obtain them? How could they be traded in the Stock Market? What related experiences to this matter already exist worldwide? In what way could you give us counseling? Could you complement our technical knowledge about swine cattle with the financial approach in order to boost our entrance into the new Carbon Bonds world?

\section{EPILOGUE}

After saying goodbye to our dear friend Mr. Jose Luis Tamez and thanking him for sharing with us the dilemmas faced by the Swine Farms Union of Nuevo Leon, we left Montemorelos with an ocean full of questions in our minds. We don't know the precise mechanisms to participate in the Carbon Bonds Trade at the Stock Exchange. Technically, what are the Carbon Bonds or RECs? How are they emitted? How are RECs quoted at the Stock Exchange? How could the swine farms venture at the Stock Exchange in order to sell these RECs? What is the trading process? Are there medium and long term risks? Is there any government support for this matter? Does Mexican legislation facilitate REC emissions? Would swine cattle farms really receive a benefit in this process? Would the involvement of the swine farms in this process be worthy? Would the world be better? Would the generation of RECs in developing countries improve the world environmental protection? How are the relations among the swine farmers, the UN, RECs emitting entities, and intermediary companies such as MGM International Group (MGM Carbon Portfolio), JP Morgan, Ecosecurities and AGCERT? How are they regulated? We should do research and learn more about this subject before venturing out to offer any type of consulting and advice to the Swine Farms Union of Nuevo Leon.

On our way back to Monterrey, all of us meditated about the subject, thinking about our great adventure and everything we learned from Mr. Tamez, when Dr. Jaime Gonzalez suddenly interrupted our thoughts by saying: - Colleagues, since the Industrial Revolution and mainly due to the intensive use of fossil fuels in industrial and transportation activities, the world is facing a serious increase of greenhouse gas emissions that have damaged the atmosphere, altogether with other serious human activities such as deforestation, that have limited the atmosphere's regenerative capacity. These changes cause a gradual increase on earth temperature, the so called climate change or global warming, which at the same time triggers other environmental problems. We have just heard about a specific case where hardworking men are trying to make an effort to contribute with the heavy duty of fighting against global warming. How could we help them?

Dr. Gonzalez continued talking with great seriousness, - while I was listening the passionate narrative of my good friend Jose Luis Tamez, I remembered some words once said by Donald McGannon, who was Executive President at Westinghouse: "Leadership is action, not a position". That is my vision of my generous friend Jose Luis Tamez. I see him as a leader looking for action. And I agree with him! Each one of us should become a role model and get involved with people, trying to inspire them as Mr. Tamez is struggling to do with the Swine Farms Union of Nuevo Leon. Let's get involved and help him! Our support to his initiative could be a way of telling our Mother Earth that we care!

Fighting to protect the environment is also a way to find the best of ourselves. I hope that, as an interdisciplinary group of professors, we could collaborate with this Swine Farms Union of Nuevo Leon and send them a concrete proposal so they can succeed on their venture of participating in the Global Carbon Bonds Trade in favor of preserving our planet.

\section{AUTHOR INFORMATION}

Flory Anette Dieck Assad, The author has a Ph.D. in Finance from Tulane University, U.S.A. in 2003. She is the author of the book "Instituciones Financieras" published by McGraw-Hill in 2003 used by all the universities of the country as textbook. She has more than 50 publications in national and international journals and peer-reviewed magazines. She is member of the Mexican National System of Researchers (SNI) from December 2005 to date. Her second book titled "Energy and Sustainable Development in Mexico" was published by "Texas A\&M University 
Press" in December 2005, which was honored with the Romulo Garza Award for book-writing in 2007. ITESM honored her achievements by giving her the "Teaching and Researching Award 2007". Currently: Associate Finance Professor of ITESM-Campus Monterrey. fdieck@itesm.mx.

\section{REFERENCES}

1. Belausteguigoitia, J.C. 1997. United States-Mexico relations: environmental issues, B. Bosworth, S. Collins, \& N. Lustig, eds. Coming together? Mexico-U.S. Relations, Bookings Institution, Washington, D.C.

2. Budedo, M.G. 1997. La política fiscal en México y los nuevos instrumentos de política ambiental, Economía ambiental: lecciones de América Latina. Instituto Nacional de Ecología, México.

3. Escalera Chávez, M.E. \& Padilla Bernal, Luz Evelia. 2009. Las granjas porcícolas, una alternativa del desarrollo rural sustentable, Ideas CONCYTEG, Año 4, No. 51, septiembre, pp1042-1050.

4. FAO, 1997. Tratamiento y utilización de residuos de origen animal, pesquero y alimenticio en la alimentación animal, Estudio FAO Producción y Sanidad Animal \# 134.

5. FAO, 2001. Los cerdos locales en los sistemas tradicionales de Producción, Estudio FAO Producción y Sanidad Animal \# 148.

6. INEGI (Instituto Nacional de Estadística y Geografía), 2008. El Sector Alimentario en México, Serie Estadísticas Sectoriales, p.66

7. Merla, Gabriela G. 2009. El mercado de Carbono en México, El Mundo del Petróleo, Año 6, No. 37, juniojulio, pp. 68-73.

8. Pérez Espejo, Rosario. 1999. Porcicultura intensiva y medio ambiente en México, Revista Mundial de Zootecnia, FAO 92, pp. 15-24.

9. Rinaldo, D \& Le Dividich, 1991. Influence de la température ambiente sur les performances de croissance du porc., INRA Prod. Anim. 4 (1): 57-65.

10. Serres, H. 1977. Précis d'élevage du proc en zone tropicale. Ministere de la Cooperation et du Developpement. Institut d'élevage et de médecine véterinaire des pays tropicaux. 45.

11. Tamez, Jose Luis, 2009. Personal interview with the owner of Ana Margarita swine farmhouse in Montemorelos, Nuevo Leon, Mexico. .

12. Zhou, M.Q.; Zeng, B.M.; Zhang, H.; Liu, Z.M.; Qi, J.Q., Cao, Y. \& Yi, J. 1997. Study on traditional swine production systems based on high fibre diets in Sichuan Province, China, Report prepared for FAO, The Animal and Veterinary Science Institute of Sichuan Province, China. 17. 
NOTES 